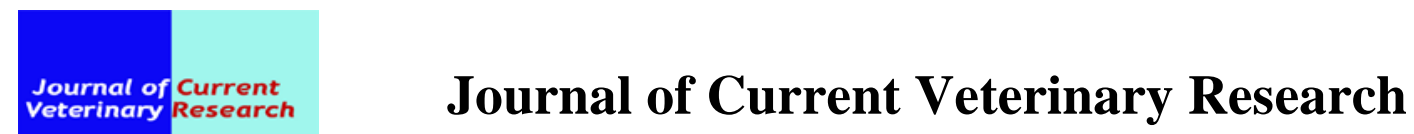

ISSN: $2636-4026$

Journal homepage:http://www.jcvr.journals.ekb.eg

Biochemistry

\title{
Ameliorative Effect of Azolla Pinnata Ethanolic Extract on Ranitidine-Induced Hepatotoxicity in Rats
}

Ahmed Shaaban Abd Elrasoul ${ }^{1}$, Ahmed Abdelmoniem Mousa ${ }^{1}$, Sahar Hassan Orabi ${ }^{1}$, Shaban M. Gad-Allah², Mabrouk Attia Abd Eldaim ${ }^{3 *}$

(1) Department of Biochemistry and Chemistry of Nutrition, Faculty of Veterinary Medicine, University of Sadat City, Sadat City, 32897 Menoufia, Egypt

(2) Department of Surgery, Faculty of Veterinary Medicine, University of Sadat City, Sadat City 32958, Egypt

(3) Department of Biochemistry and Chemistry of Nutrition, Faculty of Veterinary Medicine, Menoufia University, Sheben El-Koom, 32512, Menoufia, Egypt

*corresponding author: mabroukattia@vet.menofia.edu.egＲeceived: 6/9/2020Ａccepted: 23/9/2020

\section{ABSTRACT}

Intoxication with ranitidine is considered as one of the major causes of hepatotoxicity. The current study aimed to investigate the protective effect of an ethanolic extract from Azolla pinnate (APE) against ranitidine -induced hepatotoxicity in rats. The present study was carried out on 40 male Wister albino rats, which were randomly divided into four groups $(n=10)$. The $1^{\text {st }}$ group, control group; orally administered saline. The second group, was given ranitidine (150 $\mathrm{mg} / \mathrm{kg}$ body weight (BW) orally for 30 days); The third group, orally administered $A P E(10 \mathrm{mg} / \mathrm{kg} \mathrm{BW})$, daily for 30 days; The fourth group, was orally administrated ranitidine (as group 2), and $A P E$ (as group 3) together for 30 days. At the end of the experiment samples from blood and liver were obtained. Ranitidine increased serum activities of alanine and aspartate aminotransferases and serum levels of urea, creatinine, tumor necrosis factor alpha and interleukin-1 $\beta$ and hepatic tissue malondialdehyde contents. However, it decreased serum levels of interleukin-10 and GSH contents and catalase and superoxide dismutase activities in hepatic tissue. On the contrast, administration of rats with APE ameliorated ranitidine-induced alterations in liver function and structure stating the benefits of Azolla's phytochemical contents. Therefore, A. pinnate extract is a potential protective against ranitidine-induced hepatotoxicity via its antioxidant (presence of tamarixetin, rutin and quercetin) anti-inflammatory and antiapoptotic activities.

Keywords: Ranitidine, Hepatotoxicity, Azollapinnata, TNF- $\alpha, I L-1 \beta, I L-10$

\section{INTRODUCTION}

The main cause of hepatotoxicity in vivo system is exposure to drugs as ranitidine, toxins or compounds such as carbon tetrachloride, sodium oxalate, ethylene glycol, and heavy metals (Pal et al., 2011).

Ranitidine is a $\mathrm{H}_{2}$ antagonist used in peptic ulcer and gastro-intestinal reflux disorder (GIRD) to neutralize the acid content in the stomach and duodenum (Hemieda et al., 2005). It causes steatosis, cholestasis and induces fibrosis in portal track (Hemieda et al., 2005). It also induces proliferation in the bile duct, and sometimes presence of plasma cell, eosinophils and lymphocytes are seen due to long-term use of ranitidine (Maddox et al., 2006).

Ranitidine is a member of the class of histamine $\mathrm{H}_{2}$-receptor antagonists with antacid activity. It is a competitive and reversible inhibitor of the action of histamine, released by enterochromaffin-like (ECL) cells, at the histamine $\mathrm{H}_{2}$-receptors on parietal cells in the 
stomach, thereby inhibiting the normal and meal-stimulated secretion of stomach acid and this results in decreased gastric acid secretion and gastric volume, and reduced hydrogen ion concentration (Palmer, 2019).

Ranitidine is a histamine type 2 receptor antagonist $\left(\mathrm{H}_{2}\right.$ blocker) which is widely used for treatment of acid-peptic disease and heartburn. Ranitidine has been linked to rare instances of clinically Apparent acute liver injury. Ranitidine $\mathrm{HCl}$ is white to pale yellow, crystalline, practically odorless powder, sensitive to light and moisture. Melts at about $140^{\circ} \mathrm{C}$ with decomposition. The empirical formula is $\mathrm{C}_{13} \mathrm{H}_{22} \mathrm{~N}_{4} \mathrm{O}_{3} \mathrm{~S}$. $\mathrm{HCl}$ (Grant et al., 1989).

Under the influence of ranitidine, onset of oxidative stress occurs on account of two different pathways operative simultaneously; first comes the generation of ROS, like hydroperoxides (H2O2), singlet oxygen and hydrogen peroxide (H2O2), and second, the depletion of antioxidant reserves (Flora et al., 2007).

These free radicals also damage other tissues, including liver (Oberley, 1988) by decreasing levels of antioxidant enzymes and increasing lipid peroxidation, ranitidine lead to hepatic oxidative stress and consequently the destruction of vital organs of the rat's body (Atawodi, 2011).

AzollaPinnata is the only genus in the family Salviniaceae and has a worldwide distribution from temperate to tropical climates, Azolla pinnata is a species of fern known by several common names,

including mosquitofern, feathered

mosquitofern and water velvet. It is native to much ofAsia and Africa (Sumit and Nayak, 2014).

AzollaPinnata is an aquatic fern consisting of a short, branched, floating stem, bearing roots which hang down in the water. The leaves are alternately arranged and each consists of a thick aerial dorsal lobe containing green chlorophyll and a thin floating ventral lobe of slightly larger size that is colorless (Debashis et al., 2016).

Medicinal plant possesses an important role in human health care system. Herbal medicine has a tremendous demand in primary health sector because of their safety, efficacy, and less side effect (Baghbanan et al., 2014).

In traditional health system, herbal treatment for the liver disorder is claimed to be safest and effective, hence development and validation of newer herbal drug is of prime concern. In the development of newer therapeutic agent, animal model plays vital role (Boonstra et al., 2009). For the past 3040 years it is the animal model only that helped in better understanding various liver disorders (Arteel et al., 2010).

The chronic effect of Profenofos (broad spectrum insecticide) on Swiss albino mice can be eliminated by giving the azolla filiculoides which was a suitable antioxidant. (Arun et al., 2014).

The APEshows the presence of many bioactive compounds where considered a good source of high-quality protein (Kumar and Chander, 2017), It also contains almost all essential amino acids, vitamins, Beta-carotene, minerals, sapeonin and flavonoid (Muraleed et al., 2011).

The present study aimed to investigate the protective potential of ethanolic extract of APE against ranitidine acetate inducedhepatotoxicity in rats, and to elucidate the underlying molecular mechanism of its protective potentials as part of our ongoing project of phytochemical analysis of Egyptian plants showed antioxidant, anti-inflammatory and ant apoptotic activities (Mousa,et al., 2019).

\section{MATERIALS AND METHODS Experimental animals}

A total of 40 male Wistar albino rats, weighing 95-117 g, were purchased from Vac Sera lab., Helwan City, Cairo Governorate, Egypt. The animals were housed in polypropylene cages and kept under standard laboratory conditions of temperature $22-25^{\circ} \mathrm{C}$ and $12 \mathrm{~h}$ light/12 h dark cycle. Rats were provided with clean water and diet ad libitum. A balanced diet of commercial pellets, (table 1), (Atmida Company for international commerce and development, Egypt). The animals were kept for 10 days before the beginningof the experiments for acclimatization. Animal rearing and handling and the experimental design and procedures were approved by the Research Ethics Committee of the Faculty of Veterinary Medicine, University of Sadat City, Egypt (VUSC-006-2-20).

\section{Chemicals}

A ranitidine was purchased from the Egyptian international Pharmaceuticals industries company (EIPICO), Golf city, Cairo, Egypt. 
Diagnostic kits for assaying serum activities of alanine aminotransferase (ALT), aspartate aminotransferase (AST), and diagnostic kits for assaying serum levels of total urea, and creatinine were purchased from Diamond Company, Egypt, while kits for assaying reduced glutathione (GSH),malondialdehyde (MDA), and superoxide dismutase (SOD) and Catalase activity (CAT) content in hepatic tissue were purchased from Bio-Diagnostics Ltd., Egypt. Other chemicals used in this study were of analytic grades.

\section{Preparation of plant extract}

For preparation of $A$. pinnataethanolic extract (APE), fresh green leaves of $A$. pinnata were obtained from the botanical gardens of National Research Centre, Giza governorate, Egypt. The extract was prepared according to Selvaraj and Ranjana, (2015). Briefly, fresh leaves of $A$. pinnata were collected and dried under shade at room temperature $\left(22^{\circ} \mathrm{C}\right.$ and $65 \%$ relative humidity) for 7 days. The dried leaves were ground into powderand soaked in ethanol 70\% (500 g/ L) for 48 hrs later with gentle shaking in incubator shaker at $37^{\circ} \mathrm{C}$. The content wasfiltered through Whatman No. 1 filter paper, and the filtratewasevaporated till dryness. This extract was kept in airtight bottle in a refrigerator at $4^{\circ} \mathrm{C}$ till usage.

\section{Experimental design}

A total of 40 male Wistar albino rats were equally assigned into 4 groups, $(n=10)$.

Control group: Rats were given normal physiological saline ( $0.9 \%$ sodium chloride) orally.

A ranitidine group: Rats were orally administered ranitidine at a dose of $150 \mathrm{mg} / \mathrm{kg}$ BW for 30 daysand prepared at dose $150 \mathrm{mg} / \mathrm{kg}$ BW according to Hemieda et al. (2005).

A. pinnataethanolic extract (APE) group: Rats were orally administered $10 \mathrm{mg} / \mathrm{kg} B W$ of $A P E$. extract daily for 30 days prepared at dose $150 \mathrm{mg} / \mathrm{kg}$ BW according to Arun et al. (2014), which illustrated in the previous section.

A ranitidine and A. pinnataethanolic extract group: Rats were orally administrated withranitidine as the $2^{\text {nd }}$ group and $A P E$ as the $3^{\text {rd }}$ group simultaneously for 30 days.

\section{Sampling}

At the end of the experiment, animals were anaesthetized, then blood samples were collected from the medial canthus of the eye with heparinized capillary tube. Sera samples were separated and stored at $-20^{\circ} \mathrm{C}$ until being used for measuring the biochemical parameters. Animals were sacrificed, then liver was soon removed and kept at $-80^{\circ} \mathrm{C}$ for further investigation of lipid peroxidation and antioxidant activities biomarkers.

\section{Methods:}

\section{Preparation of tissue homogenate:}

Hepatic tissue homogenate was prepared according to Combs et al. (2011)

Hematological analysis:At the end of the experiment, animals were anaesthetized, then blood samples were collected from the medial canthus of the eye with heparinized capillary tube. Blood samples were left at room temperature for clotting. Sera samples were separated and stored at $-20^{\circ} \mathrm{C}$ until being used for measuring the biochemical parameters. Liver was removed and kept at $-80^{\circ} \mathrm{C}$ for further investigation of lipid peroxidation and antioxidant activities biomarkers.

Complete blood count (CBC) was estimated according to the methods of Tefferi et al. (2005)

\section{Biochemical assays}

Liver and kidney functions biomarkers were determined by using specific commercial diagnostic kits. Serum ALT and AST activities were analyzed according to the methods of Reitman and Frankel, (1957).

Serum levels of urea were measured according to the methods of Fawcett and Scott (1960). Serum creatinine concentration was measured according to the methods of Bartels et al. (1972).

Liver homogenate was analyzed for determination of malondialdehyde (MDA) according to the procedure described by Satoh, (1978), reduced glutathione (GSH) concentration according to the procedure described by Beutler et al. (1963), superoxide dismutase (SOD) activity according to the procedure described by Nishikimi et al. (1972) and catalase activity according to the procedure described by Fossati et al. (1980).

Determination of serum level of interleukin 1 beta (IL-1 $\beta$ ) using kit from (Bio-Diagnostics Ltd, Egypt) (Catalog No. IL 1234 ) according to Vidal et al. (2000), tumor necrosis factor alpha (TNF- $\alpha$ ) according to Brynskov et al. (2002) using kit from (Bio-Diagnostics Ltd, Egypt) (Catalog No: TF 1691), and Serum concentration of interleukin-10 (IL-10)by using kit from (Bio-Diagnostics Ltd, Egypt) 
(Catalog No: IL 2341) according to methods described by Odewumi et al. (2015).

\section{Statistical analysis:}

Analysis of results was performed by using SPSS program software version 16 (IBM $^{\circledR}$, USA). Data were subjected to analysis of variance (ANOVA) and Duncan's post-hoc tests to determine significant differences among the data. The differences between means were analyzed at the $5 \%$ probability level $(\mathrm{P} \leq 0.05)$, which was statistically significant.

\section{RESULTS}

A. pinnata extract modulated the toxic effects of ranitidine and normalized hematological parameters in different albino rat groups after 30 days (one month):

Intoxication of the rats with ranitidine elevated significantly $(P<0.05)$ RBCs countandWBCs count (Lymphocytes and Granulocytes) ascompared with the control group. However, supplementation of rats with APEduring their intoxication with ranitidine reducedsignificantly WBCs countespecially (Lymphocytes andGranulocytes) as compared with the ranitidine group. Treating of rats with $A P E$ had no significant effect on hematological parametersascompared with the control rats $(P<0.05)$ (Table 2$)$.

pinnata extract modulated the toxic effects of ranitidine on liver and kidney functions biomarkers: Intoxication of the rats with ranitidine elevated significantly $(P<0.05)$ activities of serum ALT and AST and serum levels of urea and creatinine compared with the control group. However, supplementation of rats with $A P E$ during their intoxication with ranitidine $4^{\text {th }}$ group reduced significantly activities of serum ALT and AST and serum levels of urea and creatinine as compared with rats intoxicated with ranitidine only $(P<$ 0.05).Treating of rats with $A P E$ had no significant effect on liver and kidney functions biomarkersas compared with the control rats $(P<0.05)$ (Table 3).

\section{A. pinnata extract revered the effects of ranitidine on serum levels of inflammatory and anti-inflammatory cytokines}

The administration of rats of the $2^{\text {nd }}$ group with ranitidine elevated significantly $(P<$ 0.05 ) serum levels of TNF- $\alpha$ and IL- $1 \beta$ while it reduced serum level of IL-10 as compared with the control group. However, administration of APE with ranitidine reduced significantly $(P<0.05)$ the elevated serum levels of TNF- $\alpha$ and IL-1 $\beta$, while it increased serum level of IL-10 as compared with the ranitidine intoxicated group. Supplementation of rats with $A P E$ elevated significantly $(P<$ $0.05)$ serum levels of IL-10 while it had no significant effects of serum levels of TNF- $\alpha$ and IL-1 $\beta$ as compared with the control rats.

\section{A. pinnata extract ameliorated the deleterious effects of ranitidine on oxidative/antioxidant statues in hepatic tissues of rats:}

The effects of ranitidine and/or APE on hepatic tissue lipid peroxidation and antioxidant defense system biomarkers of rats were shown in table 5. Oral administrated of the rats with ranitidine increased significantly hepatic tissue level of MDA $(\mathrm{P}<0.05)$ as compared with the normal control rats. However, administration of APE with ranitidine reduced significantly MDA contents in the hepatic tissue $(\mathrm{P}<0.05)$ as compared with ranitidine intoxicated group ( $2^{\text {nd }}$ group). On the opposite, ranitidine reduced significantly GSH contents and SOD and CAT activities in hepatic tissues of the $2^{\text {nd }}$ group as compared with the control group. However, supplementation of ranitidine intoxicated rats with APE elevated significantly GSH contents and SOD and CAT activities in hepatic tissues of $4^{\text {th }}$ group as compared with the rats intoxicated with ranitidine alone ( $2 \frac{\text { nd }}{\text { group}) . ~}$ $A P E$ itself had no significant effect on MDA and GSH contents and SOD and CAT activities in hepatic tissues of rats of the $2^{\text {nd }}$ group as compared with normal control rats (table 5).

Table (1): The ration ingredient and chemical composition

\begin{tabular}{cc}
\hline Ingredient & Composition (g \%) \\
\hline Protein & $17 \%$ \\
Fat & $4.9 \%$ \\
Vitamin mixture & $1 \%$ \\
Salt mixture & $3.5 \%$ \\
Carbohydrates & $68.16 \%$ \\
Fiber & $3.44 \%$ \\
Choline chloride & $\%$ r \\
\hline
\end{tabular}


Table (2): Hematological changes in different albino rat groups after 30 days.

\begin{tabular}{ccccc}
\hline parameters & ControlI & RanitidineII & APEIII & Ranitidine and APEIV \\
\hline RBCs & $6.33 \pm 0.13^{\mathrm{b}}$ & $7.63 \pm 0.29^{\mathrm{a}}$ & $6.44 \pm 0.28^{\mathrm{b}}$ & $6.36 \pm 0.92^{\mathrm{b}}$ \\
Hb & $11.72 \pm 0.58^{\mathrm{a}}$ & $8.17 \pm 0.33^{\mathrm{b}}$ & $10.96 \pm 0.39^{\mathrm{a}}$ & $8.2 \pm 0.73^{\mathrm{b}}$ \\
WBCs & $12.15 \pm 0.55^{\mathrm{c}}$ & $20.42 \pm 2.87^{\mathrm{a}}$ & $11.23 \pm 0.26^{\mathrm{c}}$ & $14.2 \pm 0.55^{\mathrm{b}}$ \\
Granulocytes & $7.28 \pm 0.28^{\mathrm{c}}$ & $8.19 \pm 0.47^{\mathrm{a}}$ & $7.3 \pm 0.24^{\mathrm{c}}$ & $8.68 \pm 0.75^{\mathrm{b}}$ \\
Lymphocytes & $3.35 \pm 0.37^{\mathrm{b}}$ & $11.45 \pm 0.74^{\mathrm{a}}$ & $3.15 \pm 0.63^{\mathrm{b}}$ & $5.14 \pm 0.75^{\mathrm{a}}$ \\
\hline
\end{tabular}

- The values are expressed as the means \pm SE.- Number of rats=10 - Values carrying different letters in the same row are significantly different, at $\mathrm{P} \geq 0.05-\mathrm{APE}=$ Azollapinnataethanolic extract; $\mathrm{WBCs}=$ White blood cells; RBCs = Red blood cells, $\mathrm{Hb}=$ Haemoglobin.

Table (3): Changes in some liver and kidney functions in serum theef different albino rat groups after 30 days

\begin{tabular}{ccccc}
\hline parameters & ControlI & Ranitidine II & APEIII & Ranitidine and APEIV \\
\hline ALT (U/L) & $19 \pm 2.82^{\mathrm{c}}$ & $31 \pm 0.25^{\mathrm{a}}$ & $18 \pm 2.79^{\mathrm{c}}$ & $26 \pm 2.61^{\mathrm{b}}$ \\
AST (U/L) & $112 \pm 2.35^{\mathrm{c}}$ & $161 \pm 3.50^{\mathrm{a}}$ & $113 \pm 2.48^{\mathrm{c}}$ & $132 \pm 5.69^{\mathrm{b}}$ \\
Creatinine (mg /dl) & $0.68 \pm 0.02^{\mathrm{b}}$ & $1.02 \pm 0.04^{\mathrm{a}}$ & $0.61 \pm 0.02^{\mathrm{b}}$ & $0.72 \pm 0.03^{\mathrm{b}}$ \\
Urea (mg /dl) & $18.41 \pm 1.03^{\mathrm{c}}$ & $33.03 \pm 0.75^{\mathrm{a}}$ & $20.60 \pm 0.46^{\mathrm{bc}}$ & $21.85 \pm 1.49^{\mathrm{b}}$ \\
\hline
\end{tabular}

- The values are expressed as the means \pm SE.- APE = Azollapinnataethanolic extract; ALT = Alanine aminotransferase; AST $=$ Aspartate aminotransferase - Number of rats=10- Values carrying different letters in the same row are significantly different, at $\mathrm{P} \geq 0.05$

Table (4): Changes of TNF- $\alpha$, IL-1 $\beta$ and IL-10 in serum of different albino rat groups after 30 days. The values are expressed as the means $\pm \mathrm{SE}$.

\begin{tabular}{ccccc}
\hline \multirow{2}{*}{ parameters } & Control & Ranitidine & APE & \multirow{2}{*}{ Ranitidine and APE IV } \\
\hline TNF- $\alpha(\mathrm{pg} / \mathrm{ml})$ & $81.20 \pm 2.19^{\mathrm{c}}$ & $98.79 \pm 2.23^{\mathrm{a}}$ & $80.40 \pm 2.53^{\mathrm{c}}$ & $87.50 \pm 2.66^{\mathrm{b}}$ \\
IL-1 $\beta(\mathrm{pg} / \mathrm{ml})$ & $132.20 \pm 3.22^{\mathrm{c}}$ & $174.60 \pm 2.33^{\mathrm{a}}$ & $139.20 \pm 1.93^{\mathrm{c}}$ & $162.75 \pm 3.07^{\mathrm{b}}$ \\
IL-10 $(\mathrm{pg} / \mathrm{ml})$ & $5.74 \pm 0.74^{\mathrm{b}}$ & $3.79 \pm 0.26^{\mathrm{c}}$ & $7.34 \pm 0.46^{\mathrm{a}}$ & $5.63 \pm 0.37^{\mathrm{b}}$ \\
\hline
\end{tabular}

- Number of rats=10- Values carrying different letters in the same row are significantly different, at $\mathrm{P} \geq 0.05-\mathrm{APE}=$ Azollapinnataethanolic extract; TNF- $\alpha=$ tumor necrosis factor alpha; IL-1 $\beta=$ Interleukin 1 beta; IL-10 = Interleukin 10 ,

Table (5): Changes in lipid peroxidation and antioxidant biomarkers in hepatic tissue of different albino rat groups after 30 days

\begin{tabular}{ccccc}
\hline parameters & ControlI & Ranitidine II & APEIII & Ranitidine and APE IV \\
\hline MDA (nmol/g tissue) & $7.75 \pm 0.28^{\mathrm{c}}$ & $13.44 \pm 0.27^{\mathrm{a}}$ & $8.12 \pm 0.44^{\mathrm{c}}$ & $10.42 \pm 0.33^{\mathrm{b}}$ \\
GSH (mmol/g tissue) & $2.64 \pm 0.18^{\mathrm{a}}$ & $0.69 \pm 0.06^{\mathrm{c}}$ & $2.57 \pm 0.14^{\mathrm{a}}$ & $1.82 \pm 0.13^{\mathrm{b}}$ \\
CAT (U/g tissue) & $0.64 \pm 0.01^{\mathrm{a}}$ & $0.29 \pm 0.03^{\mathrm{c}}$ & $0.60 \pm 0.01^{\mathrm{a}}$ & $0.38 \pm 0.02^{\mathrm{b}}$ \\
SOD (U/g tissue) & $3.23 \pm 0.07^{\mathrm{a}}$ & $1.87 \pm 0.05^{\mathrm{c}}$ & $3.69 \pm 0.07^{\mathrm{a}}$ & $2.93 \pm 0.09^{\mathrm{b}}$ \\
\hline
\end{tabular}

- The values are expressed as the means \pm SE.- Number of rats $=10$ - Values carrying different letters in the same row are significantly different, at P > 0.05- APE = Azollapinnataethanolic extract ; MDA = Malondialdehyde,; GSH = Reduced glutathione,; - CAT = Catalase, ; SOD = Super Oxide Dismutase,.

\section{DISCUSSION}

Ranitidine toxicity has been shown to disturb hepatic function (Parente et al., 2003). The results of the current study showed that intoxication of rats with ranitidine induced hepatotoxicity represented by elevated activities of serum ALT and AST. This finding was in line with those of Gisbert et al. (2001) who indicated that ranitidine increases the activities of serum ALT and AST. This finding may due to ranitidine induced oxidative stress in hepatic tissues as it increased hepatic tissue contents of MDA while it deceased hepatic tissues contents of GSH and activities of SOD and CAT activity (table 4). These findings agreed with that of Luyendyk,et al. (2004) who indicated that ranitidine induces oxidative stress in hepatic tissues as a result of increasing of lipid peroxidation and disturbance of the antioxidant defense system in hepatocytes. Thus, ranitidine and its metabolites induce redox cycle with the generation of superoxide radicals and hydrogen peroxide, which subsequently increase lipid peroxidation and decrease antioxidant enzyme activities 
resulting in hepatocytes destruction, activation of innate immunity by producing proinflammatory cytokines such as TNF- $\alpha$ and IL-1 $\beta$ in hepatic tissues (Francis et al., 2007). Ranitidine damages many tissues through induction of oxidative stress (Bandyopadhyay et al., 2001) also, ranitidine leading to lipid peroxidation, which induces inflammatory processes (Hitesh et al., 2012). In addition, occupational exposure of human to ranitidine increases serum levels of some proinflammatory cytokines such as IL-1, IL-6, and TNF-a (Francis et al., 2007). TNF- $\alpha$ is produced at the site of inflammation by activated macrophages and lymphocytes and participates with IL-1 $\beta$ and IL-6 to induce systemic inflammatory reactions (Turner et al., 2014). Furthermore, intoxication of rats with ranitidine in the current study decreased serum level of the anti-inflammatory cytokine IL-10 (table 4). This finding was parallel with that of Mobarakeh et al. (2000) who indicated that exposure to ranitidine decreased IL-10 in the area of cerebral cortex of rats, that finding confirmed the role of ranitidine in the development of inflammatory response in rat brain tissue (Brijesh et al., 2004). Such decrease in IL-10 due to ranitidine exposure may be implicated in the increased serum levels of IL-1 $\beta$ and promotion of inflammatory condition in ranitidine intoxicated rats as it has been indicated that IL-10 can block IL-1 $\beta$ gene expression (Wong et al., 1997). These inflammatory cytokines may injury the hepatic tissues and TNF- $\alpha$ has been indicated to induce apoptosis of hepatocytes,while inhibition of TNF- $\alpha$ production or signaling pathways reduces hepatic injury induced by TNF- $\alpha$ (Turner et al., 2014).In addition, ranitidine causes activation of innate immunity system by producing pro-inflammatory markers such as TNF- $\alpha$ and IL-1. Further, our study was in accordance with that of Francis et al. (2007) who reported that the ranitidine intoxication of rats induces hepatic tissues necrosis and increases serum transaminase activity and hepatic lipid peroxidation. Collectively ranitidine induced oxidative stress and increased pro-inflammatorymarkers.Finally, hepatic tissue injury damages hepatocytes and discharge of liver enzyme and consequently raised their activities (Selvaraj and Ranjana, 2015).

Regarding the ameliorative effects the azollapinnata alcoholic extract against ranitidine induced hepatotoxicity, our results showed that oral administration of APEE with ranitidine prevented increase inactivities of serum ALT and AST and kept serum levels of urea and creatinine (table 3 ) and hematological parameters (table 2) within normal range. These findings were in line with those of Debashis et al. (2016), who reported that $A$. pinnata reduces serum activities of ALT and AST. The ameliorative effects of APEagainst ranitidine induced hepatotoxicity may be attributed to the antioxidant and antiinflammatory activities of its constituents.A. pinnata ethanolic extract was found to be rich in flavonoids, which well-known cause their antioxidant and anti-inflammatory activities (Chen et al., 2019). In addition, quercetin and its glucoside moieties that produced by loss of glucoside annotated as quercetin-O-glucoside (hyperoside) or by loss of two glucoside unites that annotated as rutinwhich considered antioxidant (Dohaei et al., 2020). Vitexin, which is flavone C-glycoside has been demonstrated possessing anti-inflammatory activity inhibiting IL-1 $\beta$, (Borghi et al., 2013) and TNF- $\alpha$ (Park et al., 2016). Tamarixetin was investigated to exhibit superior antiinflammatory activity by reducing the secretion of several inflammatory cytokine; besides, it showed higher anti-inflammatory activity (Park et al., 2016). These compounds may reduce lipid peroxidation and inflammatory cytokines while increased antioxidant and anti-inflammatory activities as shown in tables (3 and 4) which consequently, modulatedranitidine inducedapoptosis and injury of hepatic tissues. These beneficial effects of $A P E$ against ranitidine induced hepatotoxicity confirmed the findings of Debashis et al. (2016) who indicated that APE suppresses lipid peroxidation and scavenges free radicals preventing the pathological changes in hepatic tissues architecture (Selvaraj and Ranjana, 2015). Quercetin normalizes thioacetamide increased liver function biomarkers, ALT and AST, through inhibition of change of $\mathrm{p}-\mathrm{ERK} 1 / 2$ and the increase in $\mathrm{Bax} / \mathrm{Bcl}-2$ ratio preventing cell apoptosis(Russo et al., 2014). In addition, quercetin suppresses prenatal stressincreased serum IL-1 $\beta$ levels through increasing serum IL-10 levels in rats (Wang,et al., 2012). Thus, the hepatoprotective effect of $A P E$ might attribute to free radical scavenging activity 
(De David et al., 2011). Rutin suppresses the activity of pro-inflammatory cytokines through diminishing TNF- $\alpha$ and IL-1 $\beta$ levels (Mkhize et al., 2017)

\section{CONCLUSION:}

Ranitidine induced hepatotoxicity in rats through oxidative stress increased proinflammatory cytokines and pro-apoptotic protein in hepatic tissue. However, A. pinnata alcoholic extract ameliorated ranitidine induced hepatotoxicity through reducing oxidative stress and pro-Apoptotic protein expression in hepatic tissue and proinflammatory cytokines production and increasing ani-inflammatory cytokine production and antioxidant activities in hepatic tissue. Thus, A. pinnata alcoholic extract is a considered hepatoprotective agent against ranitidine induced hepatotoxicity.

\section{REFERENCES}

Arteel, G.E. (2010). Animal models of alcoholic liver disease. Dig Dis., 28:729736.

Arun Kumar., Carib. j.,SciTech, JuliKumari,Hemant Kumar, A., Nath, J. K., Singh and Mohammad, A. (2014). Hepatoprotective and antioxidant effect of Azollafolliculoides on profenofos induced hepatotoxicity in swiss albino mice, 2: 372-377.

Atawodi, S.E. (2011), Evaluation of the hypoglycemic, hypolipidemic and antioxidant effects of methanolic extract of "Ata-Ofa” polyherbaltea Drug in alloxan induced diabetic rats. Invent. Today, 3: 270-276.

Baghbanan, H.S., Sharifian, A., Esmaeili, S. andMinaei, B. (2014). Hepatoprotective herbs, avicenna viewpoint. Iran Red Cres Med J.; 16:322-329.

Bandyopadhyay,

D., Biswas, K., Bhattacharyya, i., Reiter, R.J. and Banerjee, R.K.(2001), Gastric Toxicity and Mucosal Ulceration Induced by Oxygen-derived Reactive Species: Protection by Melatonin, current molecular medicine. Volume 1, Number 4, (13): pp. 501-513.

Bartels, H., Böhmer, M., and Heierli, C. (1972), Serum creatinine determination without protein precipitation. Clin. Chim. Acta, 37: 193-197.doi:10.1016/0009.

Beutler, E., Duron, O., and Kelly, B.M. (1963), Improved method for the determination of blood glutathione. J. Lab. Clin. Med., 61: 882-888.

Boonstra, A., van der Laan, L. J., Vanwolleghem, T., and Janssen, H.L. (2009), Experimental models for hepatitis C viral infection. Hepatoloy, 50:16461655.

Borghi, S. M., Carvalho, T. T., StaurengoFerrari, L., Hohmann, M. S., Pinge-Filho, P., Casagrande, R., andVerriJr, W. A. (2013),Vitexin inhibits inflammatory pain in mice by targeting TRPV1, oxidative stress, and cytokines. Journal of Natural Products, 76(6) : 1141-1149.

Brijesh, S., Dave, Avani, F., Amin andMadhabhai, M. (2004), Gastro retentive drug delivery system of ranitidine hydrochloride formulation and in vitro evaluation, AAPS Pharm.Sci. tech. , 5: 16.

Brynskov, J., Foegh, P., Pedersen, G., Ellervik, C., Kirkegaard, T., Bingham, A. and Saermark, T. (2002),Tumour necrosis factor alpha converting enzyme (TACE) activity in the colonic mucosa of patients with inflammatory bowel disease". Gut., 51: 37-43. doi:10.1136/gut.51.1.37. PMC 1773288. PMID 12077089.

Combs, S. E., Habermehl, D., Haase, K. Rieken, S.and Debus, J. (2011),Defining the role of palliative radiotherapy in bone metastasis from primary liver cancer: an analysis of survival and treatment efficacy. Tumori Journal,97: 609-13.

Chen, G. L., Fan, M. X., Wu, J. L., Li, N., and Guo, M. Q. (2019), Antioxidant and antiinflammatory properties of flavonoids from lotus plumule. Food chemistry, 277: 706-712.

Debashis, R., Vinod, K., Muneendra, K., Rajneesh, S., Yajuvendra, S., and Jai Kumar, S.(2016). Effect of feeding Azolla pinnata on growth performance, feed intake, nutrient digestibility and blood biochemical's of Hariana heifers fed on roughage-based diet. Indian J Dairy. Sci., 69: 503-511.

De David, C.,Rodrigues, G., Bona, S.; Meurer, L., González-Gallego, J., Tuñón, M.J. and Marroni, N.P. (2011), Role of quercetin in preventing thioacetamide-induced liver injury in rats. Toxicol.Pathol. Oct., 39: 949-957.

Dohaei, M., Karimi, K., Rahimmalek, M., andSatari, B. (2020), Integrated 
biorefinery of aquatic fern Azollafiliculoides for enhanced extraction of phenolics, protein, and lipid and methane production from the residues. Journal of Cleaner Production, 276, 123175.

Gisbert, J.P., González,L. , Calvet, X.,Roqué, M., Gabrie, l. R. and Pajares, J.M.(2001),Proton pump inhibitors versus $\mathrm{H}_{2}$-Antagonist: a meta-anal-ysis of their efficacy in treating bleeding peptic ulcer.AlimentPharamacolTher, 15:917

Kumar, G. and Chander, H.(2017). A Study on the Potential of Azollapinnata as Livestock Feed Supplement for Climate Change adaptation and Mitigation Asian J. Adv. Basic Sci., 5: 65-68.

Grant, S.M., Langtry, H.D.,and Brogden, R.N. (1989), Ranitidine: an updated review of its pharmacodynamic and pharmacokinetic properties and therapeutic use in peptic ulcer disease and other allied diseases. Drugs; 37: 801-70

Hemieda, F.A., Abdel-Hady el-SK, and Elnga, MA. (2005). Biochemical and histological studies on $\mathrm{H}_{2}$-receptor antagonist ranitidine-induced hepatotoxicity in rats. Indian J Exp Biol; 43(9):782-785.

Hitesh, K.R., Harish, C.H. and Gupta, K.R. (2012), Anti-ulcer potential of ethyl cellulose floating microspheres containing rantidine hydrochloride in experimental rodents. Asian J Pharm Clin Res.,3: 205209.

Fawcett, J.K., and Scott, J.E. (1960), Arapid and precise method for thedetermination of urea. J. Clin. Pathol., 13: 156-159. doi:10.1136/jcp.13.2.156. PMID13821779.

Flora, S.J.S., Saxena, G., and Mehta, A. (2007), Reversal of ranitidine -induced neuronal apoptosis by chelation treatment in rats: role of reactive oxygen species and intracellular $\mathrm{Ca}^{2+}$. J. Pharmacol Exp. Ther. 322:108-116.

Fossati, P., Prnicipe, L. andBerti, G. (1980), Use of 3,5-dichloro-2hydroxybenzenesulfaonic acid/4aminophenazone chromogenic system in direct enzymatic assay of uric acid in serum and urine. Clinical Chemistry, 26: $227-231$.

Francis, F., Tukov, James, P., Luyendyk, Patricia, E., Ganey and Robert, A. (2007), The Role of Tumor Necrosis Factor Alpha in Lipopolysaccharide/Ranitidine-Induced
Inflammatory LiverInjury Toxicology Sciences, 100: 267-280.

Luyendyk, J.P., Maddox, J.F., Green, C.D. and Ganey, P.E. (2004), Role of hepatic fibrin in idiosyncrasy-like liver injury from lipopolysaccharide-ranitidine coexposure in rats.In :Roth, RA.Hepatology. Dec;40(6):1342-51. doi: 10.1002/hep.20492.PMID: 15565632

Maddox, J.F., Luyendyk, J.P., Cosma, G.N., Breau, A.P.E., Bible, R.H., and Harrigan, G.G. (2006), Metabonomic evaluation of idiosyncrasy-like liver injury in rats cotreated with ranitidine and lipopolysaccharide. Toxicol. Apepl. Pharmacol; 212(1):35-44.

Mkhize, N.V.P., Qulu, L. andMabandla, M.V. (2017), The Effect of Quercetin on Proand Anti-Inflammatory Cytokines in a Prenatally Stressed Rat Model of Febrile Seizures. J Exp. Neurosci., 11:143-149. 1179069517704668.

Mousa, A.A., El-Gansh, H.A.I., AbdEldaim, M.A., Mohamed, M.A.E., Morsi. A.H., and El Sabagh, H.S. (2019). Protective effect of Moringa oleifera leaves ethanolic extract against thioacetamide-induced hepatotoxicity in rats via modulation of cellular antioxidant, apoptotic and inflammatory markers. Environ SciPollut Res., 26(31), 32488-32504. doi:10.1007/s11356-019-06368-4.

Mobarakeh, I. J., Gieras, M. U. and Gamal, D. P. (2000), Role of histamine H(1) receptor in pain perception: a study of the receptor gene knockout mice. Eur. J. Pharmacol. 391, 81-89.

Muraleed, H., Jalajakumari, M., Solomoni, J. Jonhson M. and Zachariah, M. (2011). Phytochemical studies on Azolla pinnata R. Br., Marsileaminuta L. and Salviniamolesta Mitch. Asian Pacific Journal of Tropic Biomedicine, 11: 526 529.

Nishikimi, M., Roa, N.A. and ,Yagi, K. (1972), The occurrence of superoxide anion in the reaction of reduced phenazine methosulfate and molecular oxygen. Biochem. Biophys.Res.Commun., 46:849 -854 .

Oberley, L.W. (1988),Free radicals and diabetes. Free Radical Biol. Med. 5: 113124. doi:10.1016/0891-5849 (88)90036-6.

Odewumi, C., Latinwo, L. and Sinclair, A., (2015), Effect of cadmium on the 
expression levels of interleukin-1? and interleukin-10 cytokines in human lung cells. Mol Med Rep. Nov; 12(5):6422-6. doi: 10.3892

Palmer, E (2019). Novartis doesn't wait for FDA investigation and halts distribution of its generic Zantac. Novartis on Wednesday said it was stopping worldwide distribution of its generic versions of the antacid while regulators investigate the fact that the impurity N-nitrosodimethylamine (NDMA) has been detected these ranitidine-based drugs .FiercePharma. Retrieved 20 September 2019.

Pal, A., Banerjee, B., Banerjee, T., Masih, M., and Pal, K. (2011), Hepatoprotective activity of Chenopodium album linn. plant against paracetamol induced hepatic injury in rats. Int. J. Pharm. Pharm. Sci. 3: 55-57.

Parente, F., Cucino, C., Gallus, S., Bargiggia, S., Greco, S., Pastore, L., and BianchiPorro, G. (2003), Hospital use of acid-suppressive medications and itsfallout on prescribing in general practice: a 1month survey.AlimentPharmacolTher, 17:1503-1506.

Park J. Y., Han X., Piao M. J., Oh M. C., Fernando P. M. and Kang, K. A. (2016), Hyperoside Induces Endogenous Antioxidant System to Alleviate Oxidative Stress. J. Cancer Prev., 21: 41-47.

Reitman, S., and Frankel, S. (1957). A colorimetric method for the determination of serum glutamic oxaloacetic and glutamic pyruvic transaminase. Am. J Clin. Pathol., 28: 56-63. doi:10.1093/ajcp/28.1.56. PMID:13458125.

Satoh, K., (1978), Serum lipid peroxide in cerebrovascular disorders determined by a new colorimetric method. Clin. Chim. Acta, 90: 37-43 .
Russo, M., Spagnuolo, C., Tedesco, I., Bilotto, S., Iannitti, R. and Palumbo, R. (2014), Quercetin: a pleiotropic kinase inhibitor against cancer. Cancer Treatment and Research, 159 :185-205.

Selvaraj, K. and Ranjana, C. (2015). A green chemistry Approach for the synthesis and characterization of bioactive gold nanoparticles using Azollamicrophyllaethanolic extract. Front. Mater. Sci. 8: 123-135.

Sumit, S. L., and Nayak, P. L. (2014), Green synthesis of gold nanoparticles using various extract of plants and spices. International Journal of Science Innovations and Discoveries, , 2: 325-350.

Tefferi, A., Hanson, C.A., and Inwards, D.J. (2005), How to Interpret and Pursue an Abnormal Complete Blood Cell Count in Adults. Mayo Clinic Proceedings., 80 (7): 923-936. doi:10.4065/80.7.923. ISSN 0025-6196.

Vidal-Vanaclocha, F., Fantuzzi, G., Mendoza, L., Fuentes, A. M., Anasagasti, M. J., Martin, J., Carrascal, T., Walsh, P., Reznikov, L. L., Kim, S. -H., Novick, D., Rubinstein, M. and Dinarello, C. A. (2000), IL-18 regulates IL-1-betadependent hepatic melanoma metastasis via vascular cell adhesion molecule-1. Proc. Nat. Acad. Sci., 97: 734-739.

Wong, M.L., Bongiorno, P.B., Rettori, V.,McCann, S.M. and Lici, J. (1997), Interleukin (IL) $1 \beta, \quad$ IL-1 receptor antagonist, IL-10, and IL-13 gene expression in central nervous system and anterior pituitary during systemic inflammation with pathophysiological implications. Proc. Natl. Acad. Sci. USA., 94: 227-232. 